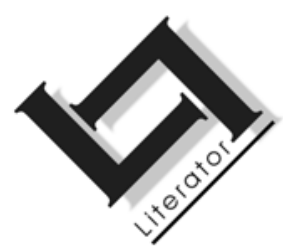

\title{
Spieëlbeelde in die werk van Ingrid Jonker en Sylvia Plath
}

\section{Gertenbach}

Departement Afrikaans

Universiteit van Kaapstad

KAAPSTAD

E-pos: ib_subed@yahoo.co.uk

\begin{abstract}
Mirror images in the work of Ingrid Jonker and Sylvia Plath

Writing poetry has an element of healing in it, but how does it work? Plath and Jonker continually wrote about mirror images, eyes and questions of identity. Different psychological theories surrounding this issue, including those of Winnicott, Jung and Lacan, are discussed. Plath's "Mirror" and "Words" as well as Jonker's "Op alle gesigte" are specifically examined. Concluding remarks reveal that a mental block, or crypt, will always force a poet to reword his/her trauma.

\section{Opsomming}

\section{Spieëlbeelde in die werk van Ingrid Jonker en Sylvia Plath}

Die skryf van poësie bevat 'n helende element, maar hoe werk dit? Jonker en Plath het voortdurend oor spieëlbeelde, oë en identiteitsvrae geskryf. Verskillende sielkundige teorieë in verband hiermee, onder andere dié van Winnicott, Jung en Lacan, word bespreek. Plath se "Mirror" en "Words" kom spesifiek ter sprake asook Jonker se "Op alle gesigte". Die gevolgtrekking dui dat 'n sielkundige struikelblok, of kripta, die digter forseer om telkens nuwe woorde vir sy/haar trauma te soek.
\end{abstract}

\section{Inleiding}

Franz Kafka het ontdek dat sy skryfwerk terapeutiese waarde het en het eenkeer gesê: "Die bestaan van 'n skrywer hang ten volle van sy lessenaar af. As hy malheid wil ontkom moet hy nooit van sy lessenaar af wegbeweeg nie. Hy moet met sy tande daaraan vasklou." (Ludwig, 1995:3.) Ingrid Jonker se uitlating: "... I found a way of 
making my own happiness and I suppose that was the beginning of my poetry" (De Vries, 1975:210) kom op dieselfde neer en Sylvia Plath beweer: "I find myself absolutely fulfilled when I have written a poem, when I'm writing one" (Lane, 1979:184). 'n Goeie hedendaagse voorbeeld van die "reddende" aspek van skryfwerk is Julia Cameron se The artist's way (1994), wat haar in staat gestel het om haar alkoholisme onder beheer te bring. Sy het sedert hierdie boek talle ander uitgegee wat almal tot 'n groter of kleiner mate suksesvol was. Die vraag is egter, wat is dit omtrent skryfwerk wat dit 'n helende aspek gee? Skryf 'n mens net weer en weer omtrent dieselfde ding (bv. spieëls) omdat 'n kernvraag daaromtrent nie beantwoord word nie?

Die antwoord lê dalk daarin dat 'n persoon se skepping, sy dit 'n gedig, 'n skildery of 'n beeld, 'n weerspieëling van sy/haar identiteit kan wees. Hierdie artikel ondersoek dié stelling aan die hand van die gebruik van spieëls in die poësie van Jonker en Plath. Sporadies word breedvoerige sielkundige teorieë uiteengesit ter verduideliking van sekere aspekte wat in die gedigte voorkom.

\section{Die spieëlbeeld}

Anne Sexton se dogter, Linda Gray, het in 1985 'n boek uitgegee, Mirror images. Hierin word die verhouding tussen 'n ma en haar dogter beskryf, asook 'n sielkundige wat nie kinders kan hê nie, maar tog die rol van 'n moeder teenoor haar pasiënte moet vertolk. 'n Beeld wat baie sterk in die roman na vore tree, is gebaseer op Mary Cassatt se skildery "Mother and child" (1905). Hier sit 'n dogtertjie op haar ma se skoot met 'n spieëltjie in haar hand. Die ma draai die dogtertjie se gewrig só dat die kind haarself kan sien eerder as haar ma en die hele beeld word deur 'n groter spieël weerkaats. Linda Sexton maak in die boek die stelling dat dit vir enige moeder belangrik is om haar kinders te wys hoe hulle lyk, eerder as om al die aandag op haarself te vestig; andersins kan dit lei tot 'n wanverhouding tussen moeder en kind - iets wat Linda Sexton en haar ma beleef het. Plath en haar ma het dit ook beleef, maar dit nooit so verwoord nie en Jonker het haar ma aan die dood afgestaan toe sy elf jaar oud was.

\section{Wat in die spieël gesien word: die selfbeeld}

Plath het skynbaar 'n obsessie met spieëls en dubbelbeelde gehad. Hierdie het met haar tesis, "The magic mirror" (Stevenson, 1998:54) begin: "on the double in Dostoyevsky, contrasting and comparing the literary treatment as it corresponds to the intention of psycho- 
logical presentation" (Wagner, 2000:45). Die spieëlbeelde in Plath se "Mirror" en "Words" hou, volgens die sielkunde van Donald Woods Winnicott, verband met die ek-spreker se verhouding met haar ma.

Voor geboorte is daar natuurlik geen skeiding of grens tussen moeder en kind nie en die baba ervaar dit steeds so kort na geboorte. Dit is belangrik dat die baba leer dat hy/sy 'n onafhanklike wese is. Winnicott redeneer dat 'n ma se gesig - spesifiek haar oë - gedurende die eerste paar weke van 'n baba se lewe die eerste spieëlbeeld van die self is (Davis \& Wallbridge, 1981:121; Jacobs, 1995: 51; Van Wyk, 1986:228). Die Franse psigoanalis, Jacques Lacan, het Winnicott se teorie beïnvloed (Davis \& Wallbridge, 1981:122) in die sin dat daar 'n interpretasie tussen moeder en kind plaasvind. Dit is nie bloot 'n geval waar die moeder na die kind kyk en eenvoudig twee oë sien nie; daar vind ook interpretasie plaas. Lacan noem dit "the gaze" (Lacan, 1977:75), waar daar nie net gekyk word nie, maar ook gewys word. Die moeder kyk na die baba en sien 'n hele wese, 'n nuwe mens en nie bloot 'n pop wat skree nie: “... such intercommunication is an urgent need for the baby" (Davis \& Wallbridge, 1981:121). As dit nie gebeur nie, soek die kind ander maniere om homself "te vind" en die moontlikheid bestaan dat 'n "vals self" kan ontwikkel.

In die ideale geval bevredig die moeder die kind se behoeftes op so 'n manier dat die kind voel hy/sy is die belangrikste wese op aarde. Die moeder is daar as ondersteuner van 'n uiters swak "self" - sy vul aan wat daaraan ontbreek. Namate die kind begin om onafhanklik op te tree en te leer dat sy/haar gedrag reaksies kan veroorsaak, begin die eie selfbeeld ontwikkel. Dit is ook ' $n$ teken dat die beeld wat die ma van die kind aan hom/haar voorgehou het, geïnternaliseer is. In die afwesigheid van so 'n wisselwerking tussen moeder en kind, waar die moeder byvoorbeeld nie aan al die kind se behoeftes voorsien nie en eerder doen wat vir háár belangrik is, sal die kind in stryd met sy/haar eie behoeftes reageer en 'n vals self ontwikkel (en doen wat hy/sy meen die moeder gelukkig sal maak). Met ander woorde, die kind sal die moeder se afwesigheid ontken asof sy steeds deel van hom/haar is (Chodorow, 1978:59-60; Davis \& Wallbridge, 1981:51).

Stevenson skryf dat Plath selfbehep was (en haar dagboeke getuig ook daarvan), "not because her ego was strong, but because it was perilously weak" (Stevenson, 1998:164). Hierdie probleem kon miskien sy oorsprong by swak moedersorg gehad het, aangesien narcisme voorkom en individuasie bemoeilik word (Kloss, 1987; Chodo- 
row, 1978:60). Plath was altyd aan die dobbel met haar identiteit. Sy wou 'n digter wees, maar ook 'n goeie vrou vir Ted Hughes en ma van sy kinders. Sy wou ook haar eie ma se verwagtings verwesenlik. Dis onmoontlik om al hierdie rolle gelyktydig perfek te kan uitvoer. Stevenson voeg by dat Plath 'n "good girl-bad girl" stryd met haarself gevoer het. Dit kom in "Two sisters of Persephone" (Plath, 1981:31) voor waar twee vroue beskryf word. Die een is soos 'n skadu binne ' $n$ huis en die ander buite in die sonlig; die een bly onvrugbaar en alleen, die ander kry 'n koning as seun. Hierdie twee vroue beeld iets uit wat Plath graag sou wou wees - maagd (maar dis nie 'n vrou nie, volgens die laaste reël) en tog vrou.

Die spieëls wat in Plath se digkuns voorkom, bied selde 'n stabiele beeld van die self, want sy kan haarself nie in verband daarmee bring nie (Lane, 1979:196). Die element wat in Plath se lewe ontbreek het, is iets wat Kloss (1987) "adequate mirroring" noem. In die afwesigheid van hierdie verband vervang die onbewuste dit met 'n ander beeld. Lacan vertel van 'n klein meisie wat vir hom gesê het sy moet iemand kry om haar op te pas "so that she might seem lovable to herself" (Lacan, 1977:257). Sonder die spieël van 'n versorger, voel die individu nutteloos en word 'n vals self uitgeleef. In die afwesigheid van 'n "ware self" verloor die lewe sy betekenis en kan ' $n$ mens selfs sy sin vir die werklikheid verloor (Davis \& Wallbridge, 1981:51). Dit kan wees dat Plath nie haar ware self uitgeleef het nie totdat sy van Hughes vervreem is. Haar gedigte was die enigste uitweg om haar ware gevoelens uit te spreek, iets wat duidelik na vore tree na aanleiding van Hughes se mening dat "By the time Plath wrote 'Poem for a Birthday' ... an old shattered self, reduced by violence to its essential core, had been repaired and renovated and born again, and ... speaks with a new voice" (Middlebrook, 2004:110). Hieruit kan 'n mens aflei dat haar "ware self" eers na 1959 na vore getree het.

'n Persoon se eie ek word deur verskillende sielkundiges op verskillende maniere uiteengesit. Carl Jung praat van individuasie - "I use the term 'individuation' to denote the process by which a person becomes a psychological 'in-dividual', that is, a separate, indivisible unity or 'whole' " (Jung, 1959:275). Wat Jung hier impliseer, is dat die psige vóór individuasie, of integrasie, uit verskeie ondergeskikte gedeeltes bestaan. Hierdie elemente word verenig deur dit wat hy individuasie noem - iets wat 'n lewenslange worsteling is. Volgens Lacan word die onbewuste deur taal gestruktureer. Dit is iets wat by Ferdinand de Saussure aansluit in die sin dat taal, volgens De Saussure, die werklikheid struktureer wat andersins 'n onsame- 
hangende massa sou wees (Cloete et al., 1985:41). Hy redeneer dat die onbewuste tot stand kom nadat taal aangeleer is en daarna funksioneer dit deur tekens, metafore en simbole. Die onbewuste is dus soos 'n taal (Appignanesi \& Garratt, 1995:88-89). Lacan verteenwoordig die stadia van psigiese ontwikkeling met die verbeelde, die simboliese en die werklike ego. Laasgenoemde val saam met Jung se individuasie, Winnicott se ware self of selfs Maslow se selfverwesenliking. Die feit dat die onbewuste vir Lacan soos taal gestruktureer is, beïnvloed ook wat in die spieël gesien word, want Lacan meen ouers sal hulle kinders voor die spieël hou en die kind daarop wys dat hy "soos ouma" of "soos niggie x" lyk. Op hierdie manier kry die kind se selfbeeld nuanses wat dit andersins nie sou gehad het nie; dit is dus 'n proses van nabootsing (Davis \& Wallbridge, 1981:51; Lacan, 1977:257).

\section{Jonker se spieëls}

In twee van Jonker se gedigte, "Ek het na die pad van my liggaam gesoek" (Jonker, 1994:50) en "Ek het gaan soek na my eie hart" (Jonker, 1994:51) soek sy iets om haarself mee te verteenwoordig. In eersgenoemde kon sy net "littekens vind in die stof / Spore van blouwildebeeste olifante en luiperds" en in laasgenoemde net "skaduwees spreeus". Miskien het die lewe haar so seergemaak dat sy onbenullig voel, veral vanweë die "littekens" wat nooit heeltemal sal weggaan nie en alleenlik tot stand kom nadat iemand seergekry het. Al wat oorbly is voetspore, of soos in die ander gedig, "skaduwees". Sy kán haarself nie vind nie, want 'n skaduwee is soos 'n voetspoor - eintlik niks nie (Gertenbach, 1997). Die spel voor twee spieëls in "Dubbelspel" (Jonker, 1994:34) bied ook geen sekerheid oor die ekspreker se identiteit nie (Van Wyk, 1986:145):

dat jy van spieël tot spieël sal draf en wonder:

as hierdie sy is, God, wie is die ander ...?

Dit lyk asof Jonker haarself telkens moes herinner aan wie sy eintlik is. Jack Cope vertel: "As the mood took her [Jonker] she swung about, would strike her forehead and say with eyes dilated: 'Yes, I am a poet - don't forget it - a poet!'” (Rabie, 1966:17). Brink vertel in 'n onderhoud dat Jonker dit geniet het om verskillende noemname te hê (Van der Merwe, 2006:251). Cope het haar byvoorbeeld "Pie" genoem en Brink se naam vir haar was "Kokon", vir haar ouma was sy "Poplap". Hierdie spel met name ontbloot haar gebroke selfbeeld/vals self. 
Die feit dat 'n spieël nie noodwendig die weerkaatsende glas in badkamers is nie, maar 'n moeder se oë, werp 'n nuwe lig op sommige van Jonker se gedigte. Van Wyk (1986:215) wys daarop dat die oë wat in Jonker se digkuns voorkom, telkens blou is soos die see en daardeur deel is van die onbewuste en van Jonker se simboliek van verdrinking. Jung meen water (die see) het 'n moederlike simboliese betekenis, en is trouens per se die simbool van die onbewuste (Jung, 1959:18). Die oë in Jonker se oeuvre is orals teenwoordig volgens "Op alle gesigte" (Jonker, 1994:47), waar die persoon se afwesigheid soos 'n obsessie in alles wat die ek-spreker raaksien, ervaar word.

\section{Op alle gesigte}

Op alle gesigte van alle mense altyd jou oë die twee broers die gebeurtenis van jou en die onwerklikheid van die wêreld

5 Alle geluide herhaal jou naam alle geboue dink dit en die plakkate die tikmasjiene raai dit en die sirenes eggo dit elke geboortekreet bevestig dit en die verwerping van die wêreld

10 My dae soek na die voertuig van jou liggaam my dae soek na die gestalte van jou naam altyd voor my in die pad van my ö̈ en my enigste vrees is besinning wat jou bloed wil verander in water

15 wat jou naam wil verander in 'n nommer en jou oë ontsê soos 'n herinnering

Hierdie gedig bevat 'n tipografiese spieëlbeeld wanneer die "jou oë" van strofe 1 teenoor die "my oë" van strofe 3 te staan kom. Waar die eerste gedeelte van die gedig nie van die blik van die oë af kan wegkom nie, probeer die tweede gedeelte die werklikheid daarvan vermy, probeer dit om van die kwessie van "bloed wat dikker as water" is, af weg te kom. Indien die aangesprokene in hierdie gedig Jonker se ma is, soos die bloedverwantskap wat in reël 14 suggereer, sal haar soeke (r. 10 en 11) altyd futiel wees. By implikasie het die spieël gebreek, soos in "Bitterbessie dagbreek" (Jonker, 1994:66), wat die ek-spreker se persoonlike gebrokenheid uitbeeld (Van der Merwe, 1991). Die ironie (veral in r. 10) is dat Jonker gemeen het sy moes "in kontak bly" met haar spieëlbeeld, soos sy gedurende haar oorsese reis aan Brink skryf: "Hier is geen spieël in 
my kamer nie en almal vind dit vreeslik lastig as jy wil gaan stort (Daar is 'n spieël by die stortbad in die kombuis). Ek vind dit nogal nodig om in kontak te bly met my eie liggaam." (Van Wyk, 1999:67.) Winnicott sou redeneer dat hierdie wens spruit uit gebrekkige moedersorg toe sy klein was. Dit sluit aan by haar behoefte om telkens "bewyse", soos foto's of (gesteelde) teelepels te hê van die plekke waar sy was of die mense met wie sy gepraat het - soos 'n "knyp om te sien of jy wakker is" (Van der Merwe, 2006:248).

\section{Plath se spieëls}

Die volgende twee gedigte word vervolgens bespreek:

\section{Mirror}

I am silver and exact. I have no preconceptions.

Whatever I see, I swallow immediately. Just as it is, unmisted by love or dislike I am not cruel, only truthful -

5 The eye of a little god, four-cornered. Most of the time I meditate on the opposite wall. It is pink, with speckles. I have looked at it so long I think it is a part of my heart. But it flickers.

Faces and darkness separate us over and over.

10 Now I am a lake. A woman bends over me.

Searching my reaches for what she really is.

Then she turns to those liars, the candles or the moon.

I see her back, and reflect it faithfully

She rewards me with tears and an agitation of hands.

15 I am important to her. She comes and goes.

Each morning it is her face that replaces the darkness. In me she has drowned a young girl, and in me an old woman

Rises toward her day after day, like a terrible fish.

\section{Words}

After whose stroke the wood rings,

And the echoes!

Echoes traveling

5 Off from the center like horses.

The sap

Wells like tears, like the

Water striving

To re-establish its mirror

10 Over the rock 
That drops and turns,

A white skull,

Eaten by weedy greens.

Years later I

15 Encounter them on the road -

Words dry and riderless,

The indefatigable hoof-taps.

While

From the bottom of the pool, fixed stars

20 Govern a life.

Plath swaai die spieëlbeeld in "Words" (Plath, 1981:270) om, omdat die water probeer om sy weerkaatsing te herstel (r. 8 en 9). Dit gebeur ook in "Mirror" (Plath, 1981:173) waar die spieël skielik 'n meer word (r. 10). Gewoonlik praat 'n mens van die meer soos 'n spieël en hier kom dit andersom voor. Sy probeer waarskynlik om beheer oor die spieëlbeeld te kry, soos die laaste twee reëls aandui.

Wie in r. 10 van "Mirror" weerkaats word, is 'n raaisel. As 'n mens na 'n spieël toe stap, sien jy jouself/die ek-spreker. Sy sien egter haar ma, of soos Kloss (1987) dit stel: "A mother does bend over her child, but at the same time it's the mother who is the lake, water being the most common symbol of birth and life". Indien die meer én die vrou wat na haarself kyk op Aurelia (Plath se ma) dui, ontbreek die ek-spreker. Die ek-spreker vertrou nóg die spieël, nóg die maan (those liars, r. 12). Hierdie feit word deur middel van herhaling in "The courage of shutting-up" (Plath, 1981:209) beklemtoon (met weerklanke van Winnicott se hipotese):

But how about the eyes, the eyes, the eyes?

Mirrors can kill and talk, they are terrible rooms

In which a torture goes on one can only watch.

The face that lived in this mirror is the face of a dead man.

Do not worry about the eyes -

Plath kyk in die spieël en sien nie net haar ma se oë nie, maar ook dié van haar oorlede pa. Plath is geneties 'n produk van haar pa én ma. Sy is ook in haar ouers se psigiese prosesse vasgevang, en dit skaad haar.

In hierdie verband is dit interessant om in Jonker se "Die waarsegster" (Jonker, 1994:29) te let op die gebruik van oë (strofe 3):

Haar oë is 'n diep poel wat verys

waarin my lewe strak en klaar verrys 
Dit weerklink die slotreëls van "Mirror", waar 'n jong vrou in die poel van die spieël verdrink, maar dit toon ook dat die oë spieëls is. Later raak hierdie blik gevaarlik (strofe 9):

Haar oë het 'n wilde kolk geword waarin my lewe skuim en stort.

Dit is weereens die oë wat die ek-spreker se lot bepaal (vergelyk "Words", fixed [reflected] stars / Govern a life). Dit skep 'n sterk kontras met die kind wat "in 'n klein poel stadig weggesink" het in "Puberteit" (Jonker, 1994:20).

\section{Die digter weerspieël haar eie ma}

Waar die spieël 'n jong meisie verdrink het, kom daar nie weer 'n jong meisie na vore nie, maar 'n ou vrou, like a terrible fish. Dit kan wees dat Plath herken het dat haar ma haarself in Plath wou uitleef en haar dogter altyd as 'n perfekte meisie wou hê. Die feit kom egter mettertyd in die misgeboorte van 'n vis voor, of volgens "Words", a white skull.

'n Jong kind verdrink in die duisternis van 'n klein poeletjie in "Puberteit". Indien die poel as simbool van die moeder gelees word, is strofe 8 'n soort beskuldiging:

Jy het nie met die ru gebaar

Die dood voorspel of die gevaar

Die teenstelling van die "ru gebaar" teenoor "stadig weggesink" (r. 3), laat die dood wreed klink. Dit is die ek-spreker se enigste besef: iets is dood, maar sy kan nie seker wees of dit die kind in haar is nie. $\mathrm{Na}$ aanleiding van die dood van haar ma, is hierdie stelling 'n verwysing na die gestorwene.

Die old woman van "Mirror" kan op 'n ouer-wordende Plath dui wat na haarself kyk. $\mathrm{Na}$ aanleiding van Winnicott se verduideliking kan dit ook wees dat sy haar ma meer en meer daarin sien. Die Jungiaanse argetipes van die wyse ou man en die groot moeder is belangrike simbole in die sin dat indien 'n mens van hulle bewus raak, die vrou van haar moeder en die man van sy vader bevry word. Sodoende word 'n mens se eie individualiteit ontdek (Degenaar, 1989). 


\section{Gevolgtrekking}

Nicolas Abraham en Maria Torok kom met die begrip kriptomnesie vorendag in hulle L'Ecorce et le noyau (Die dop en die pit) (Rand, 1990). 'n Kripta of grafkelder word gesien as die gedeelte van die psige waar skandelike (shameful) ervarings geberg word. Dit maak hierdie psigiese inhoude onuitspreekbaar:

Abraham and Torok found that patients who were tormented by unspoken secrets manifested in their speech a particular form of evasion. These patients excluded from their speech linguistic elements that would reveal the secret's contents. (Rand, 1990:58.)

Die probleem is egter dat so 'n "geheim" nie 'n talige verwantskap het nie - 'n aspek wat by Lacan se uitleg van psigiese ontwikkeling inpas, want dit kon plaasgevind het voordat woorde as betekenaars aangeleer is. Hierdie werklikheid word nie in die persoonlike onbewuste of die bewuste (om Jung se skema te gebruik) bewaar nie, maar in 'n kripta tussen die twee. "It is an enclave between the two [the dynamic Unconscious and the ego], a kind of artificial Unconscious, lodged in the very midst of the ego." (Abraham \& Torok, 1990:65.) Hulle maak van Freud se voorstelling van die psige gebruik. Dit vorm 'n gedeelte van kennis waartoe 'n mens nie toegang kan kry nie aangesien dit preverbaal is en volgens Winnicott se opvatting "threatens anxiety at possible loss and the infant's sense of existence" (Chodorow, 1978:60).

In The artist's way haal Cameron (1994:127) Jung soos volg aan: "When an inner situation is not made conscious, it appears outside as fate". Jonker en Plath het talle onbewuste beelde bewus gemaak, maar hulle het klaarblyklik nie sekere kernelemente aangeraak nie. Die aard van digkuns is nie noodwendig om betekenis oor te dra nie (Cloete et al., 1985:134). Dit is 'n nuttige linguistiese instrument waaragter psigiese waarhede kan skuil. Die psigiese waarheid wat nie geuit is nie, is dat die twee digteresse nie hulle identiteit kon plaas nie. Hulle het spieëls gesoek om hulself in te vind, maar die kripta het vir hulle leeg gebly. Om na Cassatt se skildery terug te keer: Jonker en Plath se moeders het, simbolies gesproke, nié die spieël na die kind toe gedraai nie, maar dit telkens op hulself gefokus. Die jong digters het dus grootgeword met 'n vals self. Hulle gedigte was 'n poging om die ware self te vind, maar elke gedig het net 'n gedeelte van die kern van hulle boodskap uitgedruk, soos Lacan uitwys: Al kyk iemand na homself in 'n spieël, is die werklikheid net gedeeltelik sigbaar (Lacan, 1977:72). Aangesien die 
digters nie hulle eie bestaan kon bevestig nie, het hulle altyd met vrae omtrent hulle bestaan geworstel. Hulle gedigte kon dus nie op sigself vir hulle lewegewend wees nie. Hulle kon net dieselfde trauma herhaaldelik op verskillende maniere verwoord en dit telkens anders verstaan.

\section{Geraadpleegde bronne}

ABRAHAM, N. \& TOROK, M. 1990. The topography of reality: sketching a metapsychology of secrets. The Oxford literary review, 12(1-2):63-68.

APPIGNANESI, R. \& GARRATT, C. 1995. Postmodernism for beginners. Cambridge: Icon.

CAMERON, J. 1994. The artist's way: a spiritual path to higher creativity. London: Pan.

CHODOROW, N. 1978. The reproduction of mothering. London: University of California.

CLOETE, T.T., BOTHA, E. \& MALAN, C. 1985. Gids by die literatuurstudie. Pretoria: HAUM.

DAVIS, M. \& WALLBRIDGE, D. 1981. Boundary and space: an introduction to the work of D.W. Winnicott. London: Karnac.

DE VRIES, A. 1975. Ingrid Jonker: versamelde werke. Johannesburg: Perskor.

DEGENAAR, J. 1989. Kuns as aktivering van ewige simbole. De Kat, 4:11.

GERTENBACH, I. 1997. Die skryf van poësie as uiting van 'n inherente skeppingsbehoefte met verwysing na Ingrid Jonker. Pietermartizburg: Universiteit van KwaZulu-Natal.

JACOBS, M. 1995. D.W. Winnicott. London: Sage.

JONKER, I. 1994. Versamelde werke. Kaapstad: Human \& Rousseau.

JUNG, C.G. 1959. The archetypes and the collective unconscious. London: Routledge \& Kegan Paul. (Collected works, vol. 9, part 1.)

KLOSS, R. 1987. Further reflections on Plath's "mirror". Journal of evolutionary psychology, 8(3-4):318-329.

LACAN, J. 1977. The four fundamental concepts of psycho-analysis. Translated by A. Sheridan. London: Hogarth \& Institute of Psycho-Analysis.

LANE, G. 1979. Sylvia Plath: new views on the poetry. London: Johns Hopkins University Press.

LUDWIG, A.M. 1995. The price of greatness: resolving the creativity and madness controversy. New York: Guilford.

MIDDLEBROOK, D. 2004. Her husband: Hughes and Plath - a marriage. Boston: Little Brown.

PLATH, S. 1981. Collected poems. London: Faber \& Faber.

RABIE, J. 1966. In memoriam: Ingrid Jonker. Cape Town: Human \& Rousseau.

RAND, N. 1990. Psychoanalysis with literature: an abstract of Nicolas Abraham and Mario Torok's The shell and the kernel. The Oxford literary review, 12(1-2):57-62.

STEVENSON, A. 1998. Bitter fame: a life of Sylvia Plath. London: Penguin.

VAN DER MERWE, C. 1991. Voorgeskrewe boeke vir matriek. Tydskrif vir letterkunde, 29:3.

VAN DER MERWE, L.M. 2006. Gesprekke oor Ingrid Jonker. Hermanus: Hemel en See Boeke. 
VAN WYK, J. 1986. Die dood, die minnaar en die oedipale struktuur in die Ingrid Jonker-teks. Grahamstad: Rhodes Universiteit. (Ph.D.-verhandeling.)

VAN WYK, J. 1999. Gesig van die liefde: Ingrid Jonker. Durban: Johan van Wyk.

WAGNER, E. 2000. Ariel's gift. London: Faber \& Faber.

\section{Kernbegrippe:}

Cassatt, Mary

Jonker, Ingrid

kreatiewe skryfwerk

kriptomnesie

Plath, Sylvia

spieëlbeelde

\section{Key concepts:}

Cassatt, Mary creative writing

cryptomnesia

Jonker, Ingrid

mirror images

Plath, Sylvia 